\title{
Nickel, lead and manganese content of forages irrigated with different sewage water treatments: A case study of a semiarid region (Sargodha) in Pakistan
}

\author{
Kafeel Ahmad ${ }^{1}$, Zafar Iqbal Khan ${ }^{1}$, Yasir Rizwan ${ }^{1}$, Muhammad Sher ${ }^{2}$, \\ Muhammad Khalid Mukhtar ${ }^{1}$, Rab Nawaz ${ }^{1}$, Muneeba Shaheen ${ }^{1}$, Farhad Mirzaei ${ }^{3^{*}}$ \\ ${ }^{1}$ Department of Biological Sciences, University of Sargodha, Sargodha, Pakistan \\ ${ }^{2}$ Department of Chemistry, University of Sargodha, Sargodha, Pakistan \\ ${ }^{3}$ Department of Animal Production Management, Animal Sciences Research Institute of Iran, Karaj, Iran; \\ ${ }^{*}$ Corresponding Author: farmir2001@gmail.com
}

Received 11 September 2012; revised 10 March 2013; accepted 10 April 2013

Copyright (c) 2013 Kafeel Ahmad et al. This is an open access article distributed under the Creative Commons Attribution License, which permits unrestricted use, distribution, and reproduction in any medium, provided the original work is properly cited.

\section{ABSTRACT}

The use of sewage water for agricultural purpose has tremendously increased during the last few years due to shortage of water availability, especially in semi-arid regions. Despite of many nutrients recycling advantages of sewage water, farmers are not fully aware of its harmful chemical composition. Heavy metals toxicity in soil and crops results from the long term use of sewage effluent for irrigation purposes. The present study was conducted to assess effect of sewage water on the uptake of $\mathrm{Ni}$, $\mathrm{Pb}$ and $\mathrm{Mn}$ in different forage species with respect to the nutrient requirement of the grazing ruminants in Sargodha, Punjab, Pakistan. Five samples each of six fodder species viz., Trifolium alexandrinum, Cichorium intybus, Avena sativa, Medicago polymorpha, Brassica campestris and Medicago sativa were collected from three fields irrigated with canal water, mix water (canal plus sewage water) and sewage water respectively. $\mathrm{Pb}, \mathrm{Ni}$ and $\mathrm{Mn}$ concentration in the forage species during different treatments varied from 0.624 to $1.672 \mathrm{mg} / \mathrm{g}, 7.364$ to $10.17 \mathrm{mg} / \mathrm{g}$ and 5.136 to $12.422 \mathrm{mg} / \mathrm{kg}$ respectively. High value of $\mathrm{Pb}$ and $\mathrm{Mn}$ concentrations was observed during sewage water treatment. Lead is a nonessential element and is a very toxic metal. But in the present investigation $\mathrm{Ni}$ and $\mathrm{Pb}$ level in forages were below the toxic level, so the ruminants feeding on these forage species had no chance of $\mathrm{Pb}$ and $\mathrm{Ni}$ toxicity. On the other hand, $\mathrm{Mn}$ concentration in the forage species under observation was below the critical level. So the grazing animals at this location need continued mineral supplementation of $\mathrm{Mn}$ to prevent diseases caused by Mn deficiency, and to support optimum animal productivity. The objective of this study was to examine the potential for forage analysis as indicators of likely mineral deficiencies or excesses of grazing livestock during different sewage water treatments.

Keywords: Sewage Water; Nickel; Lead; Soil; Forage; Pakistan

\section{INTRODUCTION}

One of the most serious problems facing the modern world is the shortage of water for farming and agriculture purpose. Re-use of sewage water for agriculture purposes has now gained much importance not only to overcome the water shortage but also due to nutrient recycling advantages. Also sewage farming is the best and safest way for disposing of sewage effluents. In developing countries like Pakistan sewage farming is yet practiced on small scale [1]. Treated waste water enhances crop growth and yield but also provides a wide variety of nutrients. It also serves as a water source for agriculture [2]. But on the other hand the sewage water contains varying amount of potentially harmful substances and heavy metals like $\mathrm{Fe}, \mathrm{Mn}, \mathrm{Cu}, \mathrm{Zn}, \mathrm{Pb}$ and $\mathrm{Ni}$ that cause toxicity in plants and finally in animals that feed on these plants 
[3]. All the farmers seem unaware of the harmful chemical composition of sewage water.

These harmful substances present in the soil are absorbed by the crops and become bio accumulated in the roots, stems, leaves and fruits of the crops, which may finally be transferred to the animals feeding on these plants [4]. It is generally agreed that soluble and potentially exchangeable fractions are available to the plants and biota and that are total concentration of the metals [5].

Forage plants absorb most of the minerals and heavy metals from the soil and polluted air. Most of the heavy metals have a great concern for livestock due to their toxic effects [6]. The nutrition of grazing animals is a complicated interaction of soil, plant, and animal. Plants are the main source of food for the animals. For a high yield the animals would be fed on a high protein diet concentrate. Only rarely can forages completely satisfy each of the mineral requirements for grazing. There are many diseases and abnormalities that are associated with mineral deficiencies and heavy metal toxicity. So, mineral deficiencies, toxicities or imbalances can play a major role in low animal productivity [7]. Experiments had shown that despite of presence of sufficient quantity of forage poor animal health, productivity and reproductive problems are common because of mineral deficiencies [8]. Mineral composition of forages and yield can be improved by favorable considerations like fertilizer treatment of the soil which can be made only if mineral status of the forage is known. Minerals play a major role in the immune response; the body's defense system against infectious disease, mineral supplementation above requirements is required for optimal immune responses [9]. Lead is a potential pollutant that readily accumulates in soils and sediments. It is not an essential element for plants; it gets easily absorbed and accumulated in different plant parts. Main sources of $\mathrm{Pb}$ contamination are exhaust fumes of automobiles, chimneys of factories using $\mathrm{Pb}$, effluents from the storage battery, industry, mining and smelting of $\mathrm{Pb}$ ores, metal plating and finishing operations, fertilizers, pesticides and additives in pigments and gasoline paints, gasoline and explosives as well as from the disposal of municipal sewage sludges enriched in $\mathrm{Pb}$ [10]. Due to urbanization, $\mathrm{Pb}$ and other metals are regularly discharge on to fields and garden soils through sewage sludge. $\mathrm{Pb}$ tends to accumulate in the surface ground layer and its concentration decreases with soil depth [11]. Uptake of $\mathrm{Pb}$ in plants is regulated by $\mathrm{pH}$, particle size and cation exchange capacity of the soils and other physico-chemical parameters. $\mathrm{Pb}$ toxicity in plants causes stunted growth, chlorosis and blackening of root system. $\mathrm{Pb}$ also inhibits photosynthesis, upsets mineral nutrition and water balance, changes hormonal status and affects membrane structure and permeability
[12]. However it is agreed that the bulk of the $\mathrm{Pb}$ taken up by plants remains in the roots [13]. High concentrations of $\mathrm{Pb}$ in the soil environment cause imbalance of mineral nutrients in growing plants. In most cases $\mathrm{Pb}$ blocks the entry of cations $\left(\mathrm{K}^{+}, \mathrm{Ca}, \mathrm{Mg}, \mathrm{Mn}, \mathrm{Zn}, \mathrm{Cu}\right.$, and $\mathrm{Fe}^{3+}$ ) and anions $\left(\mathrm{NO}_{3}^{-}\right)$in the root system. Nickel is an essential nutrient for plants. However, the amount of $\mathrm{Ni}$ required for normal growth of plants is very low. Plants have been shown to accumulate $\mathrm{Ni}$ in both vegetative tissues and seeds, and therefore represent a source of $\mathrm{Ni}$ to primary and secondary consumers and ultimately man [14]. Ni accumulation of 50 to $100 \mathrm{ppm}$ in leaves of plants can reduce 25 percent yield of most plants. However, nickel toxicity to cattle doesn't occur until they are fed $200 \mathrm{ppm}$ for a long period, and this is from nickel salts added to the diet. There is some evidence that the concentration of nickel tolerated might even be higher in the case of metal in the crop. Nickel does interact with other elements like iron, zinc, copper and so on, and deficiencies of these elements might make nickel more toxic to livestock [15]. Manganese is an essential trace mineral nutrient. Manganese is needed for normal brain and muscle function, building bones, blood clotting, cholesterol synthesis, fat synthesis and DNA and RNA synthesis. Manganese activates the enzyme responsible for the formation of urea, the waste product of protein degradation. In carbohydrate metabolism manganese is required for the synthesis of glucose. In addition, manganese is required to synthesize components of mucopolysaccharides (glycosaminoglycans), components of connective tissue. Mn contents were not affected by seasonal forage yield [16].

Forage Mn levels above $40 \mathrm{mg} / \mathrm{kg}$ (the critical level) found to be sufficiently higher to meet the requirements of ruminants. Uptake of copper, zinc and manganese by plants is affected by the level of phosphate fertilizer. Presence of excessive amounts of calcium and phosphorus in the diet may inhibit the absorption of Mn. Its severity depends greatly on the degree and duration of the deficiency and on the maturity of the animal [17]. Manganese requirements of cattle are poorly defined and NRC [18] suggestions for beef cattle are 20 and $40 \mathrm{mg}$ of $\mathrm{Mn} / \mathrm{kg}$ of DM for growth and reproduction, respectively. The maximum level of $\mathrm{Mn}$ in the diets for various livestock forms has been suggested as $1000 \mathrm{mg} / \mathrm{kg}$ [19]. In the Netherlands, manganese sulphate top-dressing at 15 $\mathrm{kg} / \mathrm{ha}$ has been used effectively to overcome a manganese deficiency in plants. For animals, supplementation of the feed with manganese sulphate at $4 \mathrm{~g} / \mathrm{cow}, 2 \mathrm{~g} /$ heifer or $1 \mathrm{~g} /$ calf, daily, will prevent manganese deficiency [20].

The present study was conducted to assess the uptake of $\mathrm{Ni}, \mathrm{Pb}$ and $\mathrm{Mn}$ by the forage species grown on different sewage water fields in Punjab, Pakistan. This analysis 
would allow formulation of supplementation regime for grazing ruminants to prevent the consequences of $\mathrm{Ni}, \mathrm{Pb}$ and $\mathrm{Mn}$ imbalances. The gathered information would be helpful for livestock owners in many countries including Pakistan with similar climatic conditions, thus maximizing the animal production by adopting various strategies.

\section{MATERIALS AND METHODS}

\subsection{Experimental Area}

Experimental site was representative of the natural agricultural fields of Chak No. 101 NB, District Sargodha. The fields are located $13 \mathrm{Km}$ from the centre of the Sargodha city which is being $10^{\text {th }}$ largest city of Pakistan, is an important agricultural trade centre. The district receives on the average $180 \mathrm{~mm}$ to $200 \mathrm{~mm}$ rain. The city has extreme hot and cold climate. The maximum temperature touches $50^{\circ} \mathrm{C}$ in the summer while the minimum temperature recorded is as low as freezing point in the winter.

\subsection{Samples Collection}

Six different fodder species: Trifolium alexandrinum (F1), Cichorium intybus (F2), Avena sativa (F3), Medicago polymorpha (F4), Brassica campestris (F5), Medicago sativa (F6) were collected from three different fields irrigated with canal water (T0), sewage water (T1) and mix water (canal plus sewage) (T2) respectively. Five samples of every fodder species were collected randomly from five different places in a field as described by Fick et al. [21].

\subsection{Pre-Treatment}

After carefully separating root and shoot, the samples were washed under running tap water using sieve. The fresh samples were then weighed and kept in labeled sealed paper bags and placed for drying in an oven at $100^{\circ} \mathrm{C}$ for almost 7 days. Dried samples of root and shoot of different fodder species were ground into a fine powder (80 mesh) using a commercial blender (TSK-Westpoint, France) and stored in polyethylene bags, until used for acid digestion.

\subsection{Digestion of the Samples}

The samples were than digested by the "wet digestion method". $1 \mathrm{~g}$ shoot sample was digested in with $4 \mathrm{ml}$ of $\mathrm{H}_{2} \mathrm{SO}_{4}$ and $8 \mathrm{ml}$ of $\mathrm{H}_{2} \mathrm{O}_{2}$ in a flask by placing the digesting material in digestion chamber for about 30 minutes. When fumes stop to evaporate, remove the sample from the digestion chamber. Add two $\mathrm{ml}$ of $\mathrm{H}_{2} \mathrm{O}_{2}$ and heat it again in digestion chamber. The process was continued until the sample become colorless. The digested materials was removed from the digestion chamber and made its volume up to $50 \mathrm{ml}$ with double distilled water and saved in labeled plastic bottles.

\subsection{Statistical Analysis}

$\mathrm{Ni}, \mathrm{Pb}$ and $\mathrm{Mn}$ concentrations were determined by atomic absorption spectrophotometer. The obtained data were statistically analyzed as mean $\pm \mathrm{SD}$. One way Analysis of variance (ANOVA) was used to determine significant difference between groups using the software SPSS v 18, And statistical significance was tested at 0.05 , 0.01 and 0.001 levels determined by steel and Torrie [22].

\section{RESULTS}

Analysis of variance for nickel concentration in shoot of the forage species had non-significant effect $(\mathrm{P}>0.05)$ of treatments (T0, T1 \& T2). The lowest value for nickel level in different forages during different treatments was observed in forage F3 during the treatment T2 (canal and sewage water) and the highest value for nickel concentration was that of forage F2 irrigated with canal water (T0). Ni concentration in forages during the water treatments ranged from $7.364 \mathrm{mg} / \mathrm{kg}$ to $10.17 \mathrm{mg} / \mathrm{kg}$ of dry weight.

According to Figure 1, forages F2, F3 and F5 showed gradual decrease in nickel concentration in shoot during the three treatments. While other forage species showed a consistent pattern of increased and decreased during the three treatments.

Analysis of variance for lead concentration in shoot of all the forages irrigated had non significant effect $(\mathrm{P}>$ 0.05 ) of the treatments $\mathrm{T} 0, \mathrm{~T} 1$ and $\mathrm{T} 2$. The concentration of Lead in the forage species in different treatments varied from $0.624 \mathrm{mg} / \mathrm{kg}$ to $1.672 \mathrm{mg} / \mathrm{kg}$ of dry weight. Forage type F4 treated with T2 (canal and sewage water) had the least value of $\mathrm{Pb}$ concentration, while the highest value was that of forage F6 treated with T1 (sewage water).

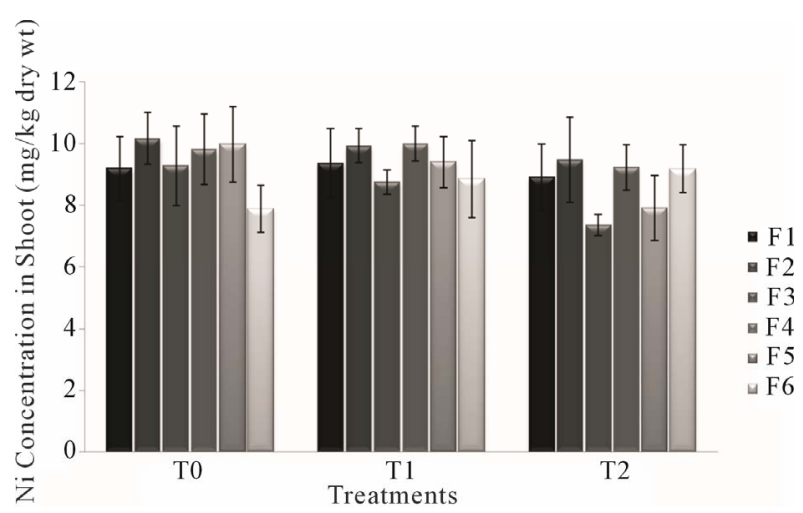

Figure 1. Fluctuation in nickel levels in shoot of different forages in different treatments. 


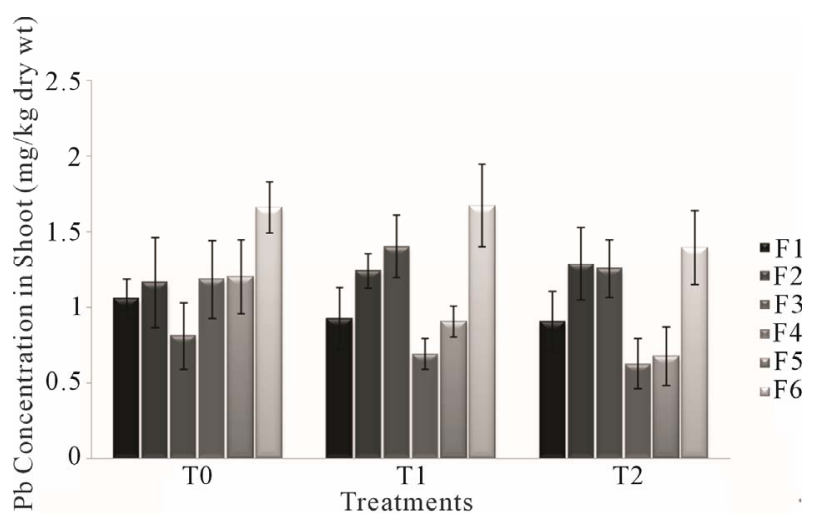

Figure 2. Fluctuation in lead levels in shoot of different forages during various treatments.

Figure 2 showed a gradual decrease in $\mathrm{Pb}$ concentration of forages F1, F4 and F5. There was a consistent pattern of increase and decrease in the $\mathrm{Pb}$ concentration accumulated in forages F2, F3 and F6.

Analysis of variance for Manganese concentration in shoot of forages F1, F3 and F6 showed non significant effect $(\mathrm{P}>0.05)$ of treatments $\mathrm{T} 0, \mathrm{~T} 1$ and $\mathrm{T} 2$ except for the forages F2, F4 and F5 which showed opposite effect $(\mathrm{P}<0.05)$ of treatments. The highest value of Mn content in shoot was that of forage F5 irrigated with sewage water, while the forage F6 possessed least value of $\mathrm{Mn}$ concentration treated with T2 (canal and sewage water). Mn concentration in the forages ranged from 5.136 $\mathrm{mg} / \mathrm{kg}$ to $12.422 \mathrm{mg} / \mathrm{kg}$ of dry weight. There was a gradual decrease in Mn level in shoot of different forages (F1, F2, F3, F4 \& F6) with respect to treatments T0, T1 \& T2, except the forage F5 in which Mn level is higher in treatment T1 (sewage water) than T0 (canal water) and T2 (canal and sewage water) according to Figure 3.

\section{DISCUSSION}

Nickel concentrations in shoot of forages found in our study were lower than the Ni level reported by Ahmad et al. [23]. Ni is a toxic metal but our investigation found that the Ni level in the forage species were below the toxic level suggested by NRC [18], so there is no threat for Ni toxicity in the grazing animals feeding on these forages. Most dietary intakes would provide sufficient amounts of this element. Nickel toxicity to cattle doesn't occur until they are fed 200 ppm for a long period, and this is from nickel salts added to the diet [24]. Higher values of $\mathrm{Pb}$ concentration in forages was observed than the $\mathrm{Pb}$ concentration in the present study by Ahmad et al. [23]. Lead is a very toxic metal. It is a non essential element. But as our observed values were below the toxic level reported by NRC [18], so the ruminants feeding on these forage species had no chance of Pb toxicity. Mean forage $\mathrm{Pb}$ concentrations were higher than the critical

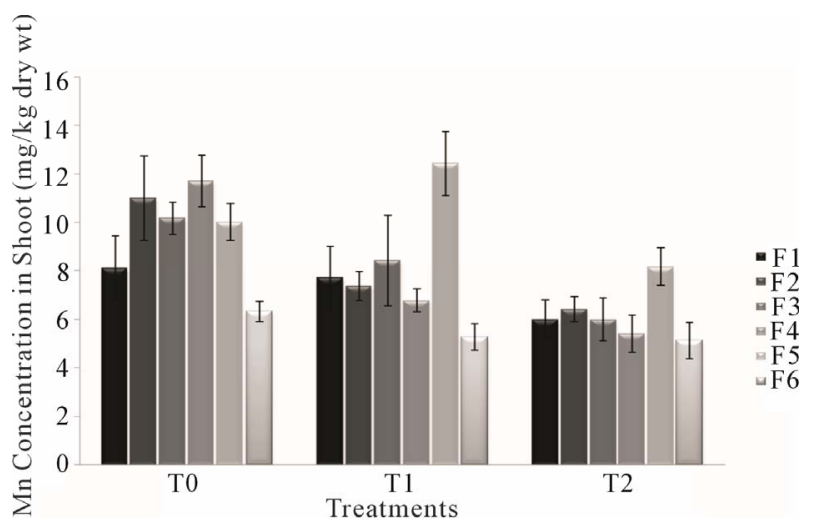

Figure 3. Fluctuation in lead levels in shoot of different forages during various treatments.

values of typical plants as suggested by Tokalioglu and Kartal [25] .The Mn concentrations in forages found during present study were higher than the Mn values reported by Hussein et al. [1], also the observed values of Mn were higher than the Mn values reported by Sultan et al. [26,27]. Mean Mn values were all below the critical level reported by NRC [18] and McDowell [28], so there is need of proper supplementation to meet the requirement of $\mathrm{Mn}$. The maximum level of $\mathrm{Mn}$ in the diets for various livestock forms has been suggested as 1000 $\mathrm{mg} / \mathrm{kg}$ [19], but in our investigation the Mn concentration has been found below this tolerable range suggesting the non toxic effect, in grazing livestock therein. The significant decrease in the plant concentration of $\mathrm{Mn}$ during the present investigation may be likely due to the formation of insoluble organic complexes (in sewage water) of Mn. The present findings are in agreement with Hue et al. [29], who reported that organic matter can regulate the availability of heavy metals through chelation reactions, in which the metals may form stable 5- or 6-membered ring structures with carboxyl and hydroxyl functional groups of organic aggregates, thus becoming a part of the solid phase that is unavailable to plants.

\section{CONCLUSION}

It is concluded that high value of $\mathrm{Pb}$ and $\mathrm{Mn}$ concentrations was observed during sewage water treatment. Lead is a non-essential element and is a very toxic metal. But in the present investigation $\mathrm{Ni}$ and $\mathrm{Pb}$ level in forages were below the toxic level, so the ruminants feeding on these forage species had no chance of $\mathrm{Pb}$ and Ni toxicity. On the other hand, Mn concentration in the forage species under observation was below the critical level. So the grazing animals at this location need continued mineral supplementation of $\mathrm{Mn}$ to prevent diseases caused by Mn deficiency, and to support optimum animal productivity. The objective of this study was to examine the potential for forage analysis as indicators of likely mineral deficiencies or excesses of grazing livestock dur- 
ing different sewage water treatments.

\section{REFERENCES}

[1] Hussein, H.F., Saber, M.S.M., Radwan, S.M.A. and AbuSeda, M. (2004) Use of treated domestic sewage effluent for growing summer oil crops in arid lands. International Conference on Water Resources \& Arid Environment, King Saud University, Riyadh, 5-8 December, 1-16.

[2] Vazquez-Montiel, O., Horan, N.J. and Mara, D.D. (1996) Management of domestic wastewater for reuse in irrigation. Water Science Technology, 33, 355-362. doi:10.1016/0273-1223(96)00438-6

[3] O’Riordan, E.G., Dodd, V.A., Fleming, G.A. and Tunney, H. (1987) The fertilizer nutrient value of an aerobically degested sewage sludges under grassland field conditions. Irish Journal of Agricultural and Food Research, 26, 199-211.

[4] Fatoki, O.S. (2000) Trace zinc and copper concentration in road side vegetation and surface soils: A measurement of local atmospheric pollution in Alice, South Africa. International Journal of Environmental Studies, 57, 501513.

[5] Adriano, D.C. (1986) Trace elements in terrestrial environments. Springer Verlag, New York, 533 p. doi:10.1007/978-1-4757-1907-9

[6] Tokalioglu, S., Kartal, S. and Gunis, A.A. (2000) Determination of heavy metals in soil extracts and plant tissues at around of zinc smelter. International Journal of Environmental Analytical Chemistry, 80, 210-217.

[7] McDowell, L.R. (1985) Calcium, phosphorus and fluorine. In: McDowell, L.R., Ed., Nutrition of Grazing Ruminants in Warm Climates, Academic Press, Orlando, 189-212.

[8] Yousseff, F.G., McDowell, L.R. and Brathwaite, R.A.I. (1999) The status of certain trace minerals and sulphur of some tropical grasses in Trinidad. Tropical Agriculture, 76, 57-62.

[9] McDowell, L.R. (1994) Feeding minerals to cattle on pasture. Animal Feed Science \& Technology, Elsevier, Gainesvile, 60, 247-271.

[10] Eick, M.J., Peak, J.D., Brady, P.V. and Pesek, J.D. (1999) Kinetics of lead adsorption and desorption on goethite: Residence time effect. Soil Science, 164, 28-39. doi:10.1097/00010694-199901000-00005

[11] Abreu, C.A., Abreu, M.F. and Andrade, J.C. (1998) Distribution of lead in the soil profile evaluated by DTPA and Mehlich-3 solutions. Bragantia, 57, 185-192.

[12] Sharma, P. and Dubey, R.S. (2005) Lead toxicity in plants. Brazilian Journal of Plant Physiology, 17, 35-52. doi:10.1590/S1677-04202005000100004

[13] Kumar, N.P.B.A., Dushenkov, V., Motto, H. and Raskin, I. (1995) Phytoextraction: The use of plants to remove heavy metals from soils. Environmental Science and Technology, 29, 1232-1238. doi:10.1021/es00005a014

[14] Cataldo, D.A., Thomas, R.G. and Raymond, E.W. (1978)
Nickel in plants, uptake kinetics using intact soybean seedlings. Plant Physiology, 62, 563-565. doi:10.1104/pp.62.4.563

[15] Chaney, R.L. and Ryan, J.A. (1994) Risk based standards for arsenic lead and cadmium in urban soils. Dechema, Frankfurt, $130 \mathrm{p}$.

[16] Arizmendi-Maldonado, D., McDowell, L.R., Sinclair, T. R., Mislevy, P., Martin, F.G. and Wilkinson, N.S. (2001) Mineral concentrations in four tropical forages as affected by increasing daylength. II. Microminerals. Communications in Soil Science and Plant Analysis, 33, 2001-2009. doi:10.1081/CSS-120004838

[17] Hays, V.W. and Swenson, M.J. (1985) Minerals and bones. 10th Edition, Dukes' Physiology of Domestic Animals, 449-466.

[18] NRC (1996) Nutrient requirements of beef cattle. 7th Edition, Nationall Academy Press, Washington DC.

[19] Anonymous (1996) Nutrient requirements of beef cattle. 7th Edition, National Academy Press, Washington DC.

[20] Underwood, E.J. (1981) The mineral nutrition of livestock. 2nd Edition, Commonwealth Agricultural Bureaux, Farnham Royal, Slough.

[21] Fick, K.R., McDowell, L.R., Miles, P.H., Wilkinson, N. S., Funk, J.D. and Conrad, J.H. (1979) Methods of mineral analysis for plant and animal tissues. 2nd Edition, Department of Animal Science, University of Florida, Gainesville.

[22] Steel, R.G.D. and Torrie, J.H. (1986) Principles and procedures of statistics. 2nd Edition, McGraw Hill Book Co. Inc., New York, 336-354.

[23] Ahmad, K., Khan, Z.I., Ashraf, M., Valeem, E.E., Shah, Z. A. and McDowell, L.R. (2009) Determination of forage concentration of lead, nickel and chromium in relation to the requirements of grazing ruminants in the salt range. Pakistan Journal of Botany, 41, 61-65.

[24] Chaney, R.L. (1990) Twenty years of land application research. Biocycle, 22, 54-57.

[25] Tokalioglu, S. and Kartal, S. (2005) Determination of Cu, $\mathrm{Pb}, \mathrm{Cd}, \mathrm{Ni}, \mathrm{Cr}, \mathrm{Co}, \mathrm{Mn}, \mathrm{Fe}$ and $\mathrm{Zn}$ in algae and vegetable samples using wet and dry ashing procedure. Trace Element \& Electrocytes, 22, 169-173.

[26] Sultan, J.I., Rahim, I.U., Yaqoob, M., Mustafa, M.I., Nawaz, H. and Akhtar, P. (2009) Nutritional evaluation of herbs as fodder source for ruminants. Pakistan Journal of Botany, 41, 2765-2776.

[27] Ahmad, K., Khan, Z.I., Ashraf, M.Y., Ashraf, M. and Valeem, E.E. (2008) Forage evaluation for some trace elements: A case study in the soone valley, Pakistan. Pakistan Journal of Botany, 40, 999-1004.

[28] McDowell, L.R. (2003) Minerals in animals and human nutrition. 2nd Edition, Elsevier Science BV, Amsterdam, $144 \mathrm{p}$.

[29] Hue, N.V., Silva, J.A. and Arifin, R. (1988) Sewage sludge-soil interactions measured by plant and soil chemical composition. Journal of Environmental Quality, 17, 384390. doi:10.2134/jeq1988.00472425001700030007x 